Research Papers in Education

\title{
Positive youth development in Turkey: a critical review of research on the social and emotional learning needs of Turkish adolescents, 2000-2012
}

\section{Robin Ann Martin \& Cengiz Alacaci}

To cite this article: Robin Ann Martin \& Cengiz Alacaci (2015) Positive youth development in Turkey: a critical review of research on the social and emotional learning needs of Turkish adolescents, 2000-2012, Research Papers in Education, 30:3, 327-346, DOI: $10.1080 / 02671522.2014 .963828$

To link to this article: https://doi.org/10.1080/02671522.2014.963828

\section{曲 Published online: 14 Oct 2014.}

\section{Submit your article to this journal $\sqsubset$}

Џ Article views: 422

View Crossmark data \lceil

Citing articles: 2 View citing articles 4 


\title{
Positive youth development in Turkey: a critical review of research on the social and emotional learning needs of Turkish adolescents, 2000-2012
}

\author{
Robin Ann Martin ${ }^{\mathrm{a} *}$ and Cengiz Alacaci ${ }^{\mathrm{b}}$ \\ ${ }^{a}$ Graduate School of Education, Bilkent University, Ankara, Turkey; ${ }^{b}$ Faculty of Educational \\ Sciences, Istanbul Medeniyet University, Goztepe, Istanbul, Turkey
}

(Received 1 March 2014; final version received 7 September 2014)

\begin{abstract}
This paper presents a critical and systematic review of 52 articles published from 2000 to 2012 about research conducted in Turkey concerning adolescents' social and emotional learning needs. In correspondence with international research, articles were examined across three categories in which adolescent needs could be addressed by educational programmes. The categories examined were attitudes toward self and others, positive social behaviours, and social skills. In conclusion, we summarise several trends along with gaps that researchers need to address to derive stronger implications for policy-making and for curriculum development that links more directly with social and emotional learning in Turkey.
\end{abstract}

Keywords: social emotional learning; adolescence; Turkey; pro-social skills; positive youth development; literature review

\section{Introduction}

\section{Research about social and emotional learning}

Education in schools is increasingly seen to include social and emotional learning (SEL) in addition to traditional forms of learning in academic areas (Bywater and Sharples 2012; Ecclestone 2012a; Elias 2013). This is partly due to the recognition that academic learning is closely related to social and emotional competencies, as well as other constructs such as emotional intelligence and well-being (Ecclestone 2012a), along with character education and citizenship (Berkowitz and Bustamante 2013). Indeed, as Elias recently reminded concerning the need for giving attention to educational policy and schools' responsibilities with respect to students' character, social and emotional development:

The challenges involved in applying knowledge are intellectual and ethical. The acts of putting knowledge into practice are inherently social. Repeatedly, we attempt to increase or improve content knowledge at the expense of social-emotional, ethical, and character development. $(2013,5)$

Since the early 1990s, several international and overlapping fields of study have supported the premise that social and emotional learning (SEL) can and should be a more explicit part of school curricula or extra-curricula. In 2012, Research Papers

*Corresponding author. Email: RMartin@bilkent.edu.tr 
in Education ran a special issue on emotional well-being, in which it was argued that there needs to be a more substantial and critical debate about the underlying premises of the need for interventions in schools (Ecclestone 2012b). In addition to evidence-based research emerging in Britain (Bywater and Sharples 2012) and America (Durlak et al. 2011), an international meta-analysis of school-based interventions within a framework of positive youth development has shown encouraging results for the effectiveness of social, emotional and behavioural programmes (Sklad et al. 2012). A thematic review of positive youth development also gives insights to the recent trends and theories in the field (Snyder and Flay 2012). In addition to historic views towards understanding the development of positive youth development (Myers 2012; Snyder and Flay 2012), there is a need to consider how research in particular countries may provide another critical lens for examining the psychosocial and emotional needs of youth. Thus, this paper aims to highlight recent research in Turkey. We argue that in spite of cultural differences, similar problems and needs arise among adolescents in countries with modern education systems. Of course, programmes cannot be carelessly adapted from one country to another. Nonetheless, school-based programmes that are successful across countries for certain types of outcomes can inform directions for further research on universal adolescent needs. In this paper, we suggest a framework for reviewing research about social and emotional learning. Instead of examining research on school-based interventions which is still scant in Turkey (Martin 2012), this framework allows us to review and discuss the needs of Turkish youth. In this way, we look into whether similar needs exist among Turkish adolescents based on evidence from universal SEL outcomes.

In addition to the emerging reviews and meta-analyses based on quantitative and mixed methods studies of positive youth development interventions, attention is also moving towards qualitative studies and theory development that could have international implications. Recently, for example, Larson (2011) and his team of researchers used qualitative longitudinal studies to examine the competencies developed by youth when working in art, community and 'youth action' projects. He proposed a grounded theory of positive youth development that considers projects in unstructured, real-world settings and how such complex systems consequently influence adolescents' emotional, motivational and cognitive development. While the research itself was based in an American context, the unfolding theory is one that could lend itself to international studies aimed at better understanding of adolescent potentials in 'how they develop and how to better support their development' (Larson 2011, 330).

\section{A framework for corresponding evidence of SEL needs in Turkey}

Although most SEL programmes researched to date are those implemented in North America and Europe, the aim of this paper is to show what adolescent needs exist as illustrated by emerging research in Turkey with respect to social and emotional learning. Even though Turkey has traditionally been portrayed as a more collectivist society (Hofstede 1993), the research trends indicate similarities with Western countries.

The present study adopted an integrated framework motivated initially by the findings of Durlak et al. (2011). We gave this meta-analysis attention because it directly linked competencies in social and emotional learning with an overall $11 \%$ 
gain in academic achievement, along with an effect size of 0.31 for targeted socialemotional skills. Cross-referencing with the international outcomes-based research, we noted two trends in Turkey. Firstly, there is a growing body of recent research that shows a need for positive youth development within Turkey. Secondly, there has also been considerable analysis of preventative problems, such as emotional distress, conduct problems and substance abuse. This article focuses on the first trend concerning the need for positive youth development programmes, with attention to research that analyses adolescents' social skills, attitudes about self and other, and positive social behaviours.

\section{Schools as curricular and developmental contexts in Turkey}

In examining research on adolescence during school years with a 'developmental systems conceptualisation', Eccles and Roeser (2011) used a three-level approach for summarising the literature. Although their review was geared towards the American schools, we feel that the framework is suitable for introducing the developmental contexts of school systems in other countries.

At the first level, Eccles and Roeser (2011) reviewed research showing the importance of teachers, tasks and classroom environments. Since 2004 in Turkey, the national education curricula have begun to integrate goals reflecting more student-centred and constructivist models of education (Aksit 2007; Öztürk 2011). Such models of education necessarily imply that teachers as well as curricula need to consider both student interests and their developmental and social needs as an integral part of learning.

With respect to teacher qualifications in Turkey, since 1998, it has been required that all high school teachers complete at least five years of university education, with about 3.5 years in a subject area and 1.5 years for pedagogy formation. Since 2005 , there has also been an option of completing a four-year bachelor's degree followed by a one-year teaching certificate programme. However, with over 850,000 teachers working in Turkey and over half of them hired in the last 10 years (Avc1 2013) and many older teachers coming from a more traditional approach of lectures only, more still needs to be done with respect to introducing a wider variety of teaching techniques that are meaningful and engaging to young people. Within this context, more will be discussed in this article with respect to teacher beliefs, student-teacher relationships and classroom emotional climate.

Pre-service teacher education can provide a chance to help future teachers develop the skills to meet students' social and emotional needs in school environments. Currently, teacher education programmes in Turkey require one course in educational psychology and one course in guidance counselling. The educational psychology course is often entirely devoted to learning in cognitive theory or from traditional academic perspectives. The guidance class gives some attention to students' social and emotional development; however, the approach is generally lecture-based, and pre-service teachers have limited opportunity to think beyond the teaching of their subject matter and to engage in meeting students' needs beyond academics.

At the second level of analysis (Eccles and Roeser 2011), developmental research is also becoming more conclusive with respect to school-wide characteristics that show the importance of schools as cultures for academic engagement and learning as well as safe places with student diversity. With respect to the former, this present article points out a need to examine Turkish schools and learning outcomes 
from the perspective of schools as cultural systems. With respect to safety in Turkish schools, Turkey is in fact known to have some of the highest rates of bullying among a number of countries studied (Craig et al. 2009; Harel-Fisch et al. 2011). With respect to diversity, while ethnicity is not yet well researched in terms of disadvantages to students, research among OECD countries indicates that in Turkey, the biggest disadvantage for learning outcomes is based on school types, with students who attend vocational high schools appearing as the most disadvantaged (Alacaci and Erbaş 2010; Gumus and Atalmis 2012). In particular, Alacaci and Erbaş (2010) and OECD (2013) showed that as much as 50 to $55 \%$ of variance in student achievement as measured by the Programme for International Student Assessment (PISA) was explained by school factors including SES background and school selectivity of students. Furthermore, schools are quite homogenous in terms of student socio-economic background. These indicate low levels of social and academic inclusion in Turkish schools serving adolescents (OECD 2013).

At the third level, let us consider briefly national policies and practices that could influence student development. According to Eccles and Roeser (2011), research reveals that some of the important issues to consider with respect to adolescent development include grade level groupings and school transitions, school sizes, tracking policies and extra-curricular offerings (with particular attention to service learning). In terms of grade level groupings, Turkey switched its grade configurations in 2012; however, for most of the time period analysed by studies in this review, primary schools were grades 1 to 5, upper primary were grades 6-8 and high school was grades 9-12. One could say though that when the change was made to a new 4-4-4 approach in 2012, relatively little of the public discourse was on the developmental needs of students with respect to research about the difficulties faced by adolescents during school transitions such as those cited by Eccles and Roeser (2011).

Due also to the new 4-4-4 structure, grades 6-8 are no longer considered as part of the upper elementary schools, and grade 5 students are now part of the middle schools rather than the lower elementary school. In developing new positive SEL programmes for youth, or in the extent to which old programmes for youth development had been studied, such programmes now need to be re-evaluated. As students' attitudes as well as academic and social factors are no longer situated in the context of their upper elementary schools, there is a need for collecting new formative data, especially for students in grades 5-8. Indeed, adolescent attitudes as described in this paper could also shift as career guidance programmes or other environmental factors in the schools are modified to accommodate the new 4-4-4 structure. Thus, the data summarised in this paper capture only one point in time in a shifting educational system.

Class sizes vary considerably across school types in Turkey. While selective specialty schools such as science high schools and social science high schools have smaller class sizes (with average sizes of 19 and 16, respectively), vocational high schools and general high schools have bigger classes (averaging 36 and 42, respectively) and these schools educate by far the largest portion of student body with $87 \%$ (Ministry of National Education 2013). While some research is beginning to show the relation between school and class size and achievement in Turkey (Kiliç, Çene, and Demir 2012), more research is yet needed to examine the relation between class size and learning outcomes.

In terms of tracking policies, even in more developed countries, it appears that research is still sketchy with 'few strong and definitive answers' (Eccles and Roeser 
2011, 235). Indeed, tracking may influence high- and low-ability students in different ways, as well as influencing their academic performance differently from their self-concepts. In Turkey, tracking is done mostly at the school level, not at the programme level. In other words, after grade 4, students begin to track different types of schools based on their test scores (not usually on their own career interests, so much as what they are capable of doing). By grade 8 , students and their families must choose (based mostly on testing) between Anatolian (general) high school (or lycee), science high school and social science high school - which all are explicitly linked to university entrance in their curriculum designs, versus the less-likely-to-beuniversity-bound options of technical, vocational, or sports and arts high schools. From an identity and social development perspective, this policy could be seen as foreclosing student options from their very first step into high school. Recently, there have been deliberate steps to reduce tracking by school type by reducing disparities of what schools offer for preparation to higher education (Avc1 2013).

Also, at the national level of policy in Turkey, educational goals set out by the Ministry of National Education for different levels make deliberate reference to social and emotional learning in schools. According to basic law of national education (Law \#1739), the general goal of Turkish National Education includes:

To help (students) grow physically, cognitively, spiritually and emotionally to become healthy and balanced individuals who value freedom, have the capability to reason scientifically, respectful of human rights, individuals and initiatives, who have a sense of responsibility toward society, and are constructive, creative and productive in their lives. (Ministry of National Education 1973)

According to official documents of the Ministry, the new curriculum aims 'to help students develop psychologically, socially, morally and culturally into healthy and balanced individuals who pursue happiness and self-actualization in life'. Another new curricular goal is to help students develop awareness of their rights, and responsibilities to adjust well into the society, appreciating human rights and valuing democratic culture (Ministry of National Education 2005). While these goals may be arguably more rooted in the written curriculum than the delivered curriculum, they are nonetheless worth noting as stated aims related to the social and emotional development of young people.

\section{Research questions}

In considering the international research on social and emotional learning in the light of the emerging curricular trends in Turkey, two enquiry questions emerged:

(1) What are the descriptive characteristics of the recently published research concerning adolescents' attitudes towards self and others, as well as their positive social behaviours? (Language, type of journals, sampling and methods, geographical locations in Turkey)

(2) What trends does the published research indicate about the needs and experiences of Turkish adolescents in terms of:

(a) attitudes towards self and others?

(b) social skills?

(c) positive social behaviours? 
After analysing findings on these questions across 52 articles, we discuss recommendations about how these findings can be utilised in curriculum development, as well as gaps that need to be bridged to create a fuller understanding of adolescent needs in Turkey.

\section{Methodology}

To cover the largest scope of high-quality research, we opted for a three-part approach that examined articles published in both English and Turkish journals. Firstly, we found 52 articles published in international journals using systematic and extensive keyword strategies in major databases to locate empirical studies on social and emotional learning for adolescents. Secondly, we searched four Turkish general education journals that had been accepted in the Social-Science Citation Index (SSCI) as an international indicator of quality. (Currently, the four general education journals that are SSCI in Turkey are: Eğitim ve Bilim or Education and Science, Kuram ve Uygulamada Eğitim Bilimleri or Educational Science in Theory and Practice, Hacettepe Universitesi Eğitim Fakultesi Dergisi or Hacettepe University Journal of the Faculty of Education and Eğitim Araştırmalarl or Eurasian Journal of Educational Research.) We reviewed the tables of contents and abstracts to locate relevant articles from 2000 to 2012, regardless of when they became SSCI journals. Thirdly, we identified references cited in the previously located articles that met our inclusion and exclusion criteria. During this final search, articles were found from several other Turkish and SSCI journals in the fields of health and psychiatry.

For all three parts of this search, we used the following inclusion criteria to focus our review:

- Research about adolescents (ages 11 to 17), grades 6 to 12. In Turkey, until a recent change in 2012, grades 6 to 8 were part of elementary schools. So, for research in elementary schools, we checked whether data for grades 6,7 and 8 had been separated to indicate trends especially for these upper elementary levels.

- Research about the needs for positive youth development, based on keyword searches that encompass Turkish adolescents' attitudes about self and other, along with positive social behaviours and social skills.

We removed articles that only discussed or reviewed other people's research without including any data from an original study. In addition, in an effort to focus on the normal adolescent development during their secondary school years, we excluded research about late adolescence in university years, students' attitudes and interests about subject areas, special education, counsellor education and teacher education.

\section{Descriptive characteristics of articles reviewed}

Forty percent of the studies were published in Turkish primarily (often with an abstract or one-page summary in English), and the remaining 60\% were in English. For this collection of 52 articles, $56 \%$ were published in SSCI journals, as an indication of the quality of research included. Another characteristic of these articles was that over $80 \%$ were strictly quantitative studies. Even when we conducted keyword 
searches to locate qualitative research such as case studies, we found only seven qualitative studies and two with mixed methods.

A fourth characteristic of the analysed research was a focus on urban populations. The population of Turkey was nearly 76 million in 2012 with about 57 million living in medium-sized to large cities (population figures from Turkish Statistical Institute, 2012). In other words, $77 \%$ of the population of Turkey lives in urban areas. It is thus startling to note that only one study was found that examined adolescents in rural areas, which contain $23 \%$ of the population. Indeed, most of these studies - 29 out of 52 , or $56 \%$ - were conducted in nine of the largest cities of Turkey with a population of more than one million, with two studies not reporting their locations.

Another notable characteristic was the year of publication. There was no study published prior to 2002. From 2002 to $2007,25 \%$ (or 13 studies) were located, and the remainder were published from 2008 to 2012, with 20 (over one-third) of the sample in 2012 alone. This shows that research on the topic has gained momentum in recent years.

With respect to sample sizes, among the quantitative studies examined, sample sizes varied from 132 to 1582 students, and were generalised appropriately. Of course, it should be noted that none of the studies were replication studies to show how such findings could be duplicated when examining populations from different cities or of different ages. Perhaps, replication studies could be located in an analysis of MA theses. Finally, with respect to our summary of findings, we have generalised in some cases with respect to not citing the cities and the adolescents' particular ages for many studies, in the interest of looking for patterns and trends. As such research in Turkey expands, it would be worthwhile to look more carefully at differences across cities and adolescent age groups.

\section{Summary of research about SEL among Turkish adolescents}

In summarising the research, we categorised each study in terms of the depth of research conducted: (1) descriptive studies predominantly include survey research, with some basic correlations with respect to demographic variables and (2) studies of mediating variables in which researchers examined factors of family, school, personal characteristics or peer relationships that may influence the given attitudes, skills or behaviours.

A growing body of studies exists indicating how Turkish adolescents may need further support in developing healthy attitudes towards self and others. Meanwhile, there is a scarcity of studies that summarise social skills and positive social behaviours of adolescents (Table 1). In fact, so few studies were found about positive social behaviours, that we collapsed that category with social skills in the text that follows. More research evidence is necessary to document Turkish adolescents' social skills and behaviours, especially pertaining to family- and school-based factors that may influence the development of positive social behaviours.

With respect to the influence of social and emotional learning on academic achievement, and vice versa, a handful of studies were found that made direct links between SEL competencies and academic achievement (Yildirim 2000, 2006; Gizir and Aydin 2009). One study made links between academic motivation and strategies for improving subjective well-being (Eryilmaz 2011), and another examined the relationship between negative auto thoughts and intrinsic achievement motivation 
Table 1. Summary of 52 Turkish educational research articles about SEL.

\begin{tabular}{lccc}
\hline $\begin{array}{l}\text { Evidence-based SEL outcomes, as } \\
\text { per international research }\end{array}$ & $\begin{array}{c}\text { Descriptive studies } \\
\text { with demographic } \\
\text { variables only }\end{array}$ & $\begin{array}{c}\text { Studies of mediating } \\
\text { variables for Turkish } \\
\text { adolescents }\end{array}$ & Total \\
\hline $\begin{array}{l}\text { Attitudes towards self and others: } \\
\begin{array}{l}\text { Surveys of perceptions, beliefs, } \\
\text { social values }\end{array}\end{array}$ & 11 & 30 & 41 \\
$\begin{array}{l}\text { Positive social skills and } \\
\text { behaviours: Inventories, } \\
\text { observable indicators }\end{array}$ & 7 & 4 & 11 \\
Total & 18 & 34 & 52 \\
\hline
\end{tabular}

(Kapikiran 2012). These studies were few in number and differed considerably in foci, so that they were not examined in the current review. Furthermore, we did not include articles that were about improving social skills based on intervention programmes, as they go beyond the 'needs' scope of this review and these studies were summarised elsewhere (Martin 2012).

\section{Analysis of Turkish adolescents' SEL needs Attitudes towards self and others: descriptive studies}

Within international research, the category of 'attitudes toward self and others' shows itself in several ways, according to the angles from which reviewers study SEL, such as preventative programmes versus positive youth development. Sklad et al. (2012) discussed the direct outcomes of positive self-image, while Weare and Nind (2011) found outcomes they called as self-confidence and self-esteem. For this review, the Turkish educational research seemed in keeping with an outcome that Durlak et al. (2011) called as attitudes towards self and others to encompass 'attitudes about self, school, and social topics' which includes self-perceptions, school bonding and beliefs about society and social values. Of the 52 articles reviewed in this study, we found five descriptive studies that painted a mixed picture of how Turkish adolescents see themselves and their own lives, along with six studies that focused on Turkish adolescents' social values - how they see society, including school.

Within the five studies concerning self-images, Cenkseven (2002) examined internalised gender roles, with female adolescents indicating better impulse control, more 'relaxed' and 'positive' attitudes towards the opposite sex, and better mental health; male adolescents showed attitudes of greater harmony with the social environment.

Other studies examined issues of how adolescents as well as their teachers perceive their guidance and counselling needs (Kesici 2007a, 2007b). Most students reported that they need guidance especially in effective studying techniques (Kesici 2007a), while teachers felt that students show a wider range of needs encompassing also physical, psychological and family problems (Kesici 2007b). Another study found a very low degree of awareness among seventh grade students of what leisure activities can (and should) be done outside of academics to engage in a healthy life style (Aslan and Arslan Cansever 2012), such as sports or other social activities beyond the Internet. 
Within the six studies that examined Turkish adolescents' attitudes towards others, three focused on general social attitudes and values (Doğanay 2010; Özabacı 2011; Taşdemir 2012), while two were specifically about school (Telli, Brok, and Çakıroğlu 2008; Altıparmak et al. 2012) and one concerned adolescent attitudes about the separation-individuation process with their parents (Güven and Aslan 2010). Overall, there were fewer descriptive studies about attitudes, with about twice as many attitudinal studies that focused on predictive and correlational factors as described in the following section. Nonetheless, together these attitudinal studies indicate a need for researchers to further examine, or at least discuss, the explicit and implicit school curricula in tandem with findings, so that the development of attitudes can be understood in the context of the students' school lives, and beyond socio-demographic variables.

\section{Attitudes towards self and others: mediating factors}

Thirty of the 52 studies used mostly correlational, ANOVA and regression methods to reveal the strength of relations with mediating variables concerning students' attitudes towards self and others, as discussed below. The attitudes examined were primarily positive attitudes about self, assessed through constructs such as life satisfaction, self-esteem, emotional well-being and resilience. A few studies examined attitudes with more social dimensions such as social relations, friendship quality and school perceptions. Also, a few negative attitudes were studied including mistrust, loneliness and negative affect.

Setting aside demographic variables that cannot be altered or addressed by interventions in school settings, such as gender and age, the mediating factors most commonly examined (in over two-thirds of these 30 studies) were student characteristics such as motivation, perceptions and decision-making styles. In other words, these studies were predominantly psychological in nature, examining how one set of personal characteristics is associated with another set. School variables and family (or home-related) variables were each examined in about one-third of the correlational studies. Peer relationships were examined in only three of the studies, and neither culture nor media were considered as mediating factors of adolescents' attitudes in any of these studies.

Studies that focused especially on student characteristics that influence their attitudes shed light on possible SEL competencies that could be integrated into Turkish curricula. One study showed how 'empathetic tendency predicted responsibility, friendship, pacifism, honesty and tolerance' among high school students (Dereli and Aypay 2012, 1262). In another study, decision-making styles characterised by 'vigilance' (carefully examining life decisions by assessing alternatives) were correlated with stronger perceived life satisfaction (Cenkseven-Önder 2012). Other student characteristics found to be facilitative of students' positive attitudes were their coping strategies (Aricak et al. 2008), perceived academic school achievement and accomplishments (Çivitci 2009; Geçk1l and Dündar 2011; Arslan 2012) and attachment styles (Çetin et al. 2010; Doğan et al. 2012). Studies in attachment styles of adolescents align especially well with trends beyond Turkey that show how attachment styles may change as a child grows older and are not tied only to parents' attachment or the current parent-adolescent relationship (Allen and Manning 2007, 25). This research shows links between attachment and affect regulation during adolescence. Together with the Turkish studies, this suggests personal attributes such as 
empathetic tendency, decision-making styles and coping strategies that may facilitate social and emotional development, and that could be integrated more directly into curricular goals and objectives with attention to students' SEL.

Also noteworthy are factors found to inhibit Turkish adolescents' positive attitudes about self and others. Inhibitive factors included social phobia linked with a lower self-concept (Bayramkaya, Toros, and Özge 2005), involvement in bullying that negatively influences students' perceptions of their school (Bayar and Uçanok 2012) and attitudes such as human nature not being reliable that in turn influence adolescents' mistrust of others (Akbaş 2012). Together, these studies support evidence from elsewhere (e.g. Lambert et al. 2008) that schools need clear rules on negative social behaviours such as bullying, and that understanding the sources of negative attitudes may directly influence classroom environments.

The most common school variable examined was school type. School type (such as science high schools, Anatolian high schools, Anatolian teacher high schools, technical schools and vocational schools) was found to be correlated with differing levels of adolescent autonomy (Öngen 2004), emotional intelligence (Titrek 2009), perceptions of teacher-student relationships (Balay, Kaya, and Doğu 2012), perfectionism (Camadan and Yüksel 2012), general perceptions of school (M. Özdemir 2012) and resilience (Yilmaz and Sipahioğlu 2012). Together, these studies point towards how the admission strategies used to place students into different types of schools, by their nature, may also influence the variety of personal characteristics of students within these schools. The extent to which these limitations on student diversity are beneficial or detrimental to students either within the given schools or within the society at large could be explored further.

Within the school-related variables, four studies discussed how academic achievement corresponds with attitudes of self. These studies showed positive relations between academic achievement and performance with high emotional intelligence levels perceived by teachers (Titrek 2009), subscales of perfectionism (Camadan and Yüksel 2012), a sense of belonging (Sar1 2012) and self-efficacy beliefs (Arslan 2012). However, it should be noted that one study used school type as an indicator of achievement, another did not report how it assessed achievement and two used students' self-reports. Also notable was one study that examined how school activities could influence adolescents' attitudes and found that 'both playing an instrument and joining a band [had] low but positive and significant correlation with life satisfaction' (Kapikiran and Yağc1 2012, 738).

In this set of studies, home environment or family-related variables considered a wider array of issues than the school variables, including socio-economic status, parents' educational levels, family composition (number of siblings), parental income and parental support-caring relationships. While these factors are less controllable, they do indicate a need for family programmes, possibly within schools, that give particular attention to supporting the positive attitudes of children with various socioeconomic related problems. While one study indicated that students from families with lower income had more positive attitudes about school (M. Özdemir 2012), another study indicated that parental income was positively associated with higher life satisfaction (Y. Özdemir 2012). Meanwhile, interesting findings with respect to parents' levels of education emerged as well. For example, students with fathers who graduated from high school had higher scores with respect to social acceptance and 'pacifism' - presumably, the attitude that violence is not justifiable as a means for resolving conflict (Dereli and Aypay 2012, 1266). Another study showed that a 
'companionship' subscale of friendship qualities was best predicted firstly by the father's level of education and secondly by the mother's level (Yilmaz and Sipahioğlu 2012). Understanding such differences in Turkish students' family backgrounds and their links to SEL competencies can help guide the design of school programmes for positive youth development, including counselling programmes.

While each study paints only a partial picture, together, these correlational studies imply that supporting the development of students' SEL competencies, such as empathy, coping strategies and decision-making, can help young people in Turkey to become more well adjusted in their lives. These topics correspond well with supporting international research about the protective factors for positive mental health (e.g. Weare and Nind 2011). Of course, replication studies at different times and using different populations of adolescents from varied cities and rural areas would also shed further light on the situation in Turkey.

\section{Positive social skills and behaviours: descriptive studies}

We also looked for research that explicitly investigated social skills, including skill assessments based on reports from students, teachers, parents or independent raters. Topics could cover 'cognitive, affective and social skills related to such areas as identifying emotions from social cues, goal setting, perspective taking, interpersonal problem solving, conflict resolution, and decision making' (Durlak et al. 2011, 410). As this category of studies numbered fewer than four, we consider them together with social behaviours, which reported daily behaviours of students. In total, we located seven studies describing either or both social skills and positive social behaviours. These studies examined coping strategies (Öngen 2002), pro-social moral reasoning (Kumru et al. 2012), social skills in general (Bacanlı and Erdoğan 2003; Kabakç1 and Korkut 2008) as well as those specific to conflict resolution and interpersonal problem-solving (Türnüklü, Şahin, and Öztürk 2002; Türnüklü and Şahin 2004; Sar1, Sarı, and Ötünç 2008).

Two studies about how adolescents address personal problems showed a lack of strategies for peaceful and constructive solutions among both female and male students, and that psychologically and physically violent strategies were common (Türnüklü, Şahin, and Öztürk 2002; Türnüklü and Şahin 2004). It is possible that these two studies took place in the same schools. Nonetheless, the results should evoke concern about potentially harsh school climates in Turkey, underscoring the need for SEL support at large. Another study examined students' 'devotion to democratic values and conflict resolution' (Sarı, Sarı, and Ötünç 2008). In contrast to the previous results, the authors concluded that, 'In short, results show that students ... had high democratic values and conflict resolution abilities... and that there were significant correlations between devotion to democratic values and conflict resolution abilities' $(2008,183)$. Unfortunately, little can be gleaned from the article about the social milieu or school context in which the data were collected.

Among studies that examined gender differences, Turkish females showed stronger social skills, communication and conflict resolution abilities than males. Such gender differences were attributed to socialisation and social expectations (Bacanlı and Erdoğan 2003), or social norms and gender roles (Kabakçı and Korkut 2008), but not to biological maturation. Given that, biologically, girls mature earlier than boys by about two years (Santrock 2001, 46), authors minimised the maturation factor in their discussions. 


\section{Positive social behaviours: mediating factors}

Four studies were related to mediating variables that influenced positive social behaviours, such as students' own characteristics, family variables or school-based activities. All were about students' daily behaviours and not assessments of their skills. One article based on evidence provided by teachers concerning their use of the affective domain in classrooms (Biçak 2003) showed that teachers with more pedagogical training have more positive attitudes towards the affective domain, but that nonetheless did not indicate that they necessarily applied the affective domain in their classrooms. A study that used observations of teacher-student relationships (İpek and Terzi 2010) showed that teachers in primary schools and those with more than 10 years of experience were the ones most likely to have stronger teacherstudent relationships. Based on data from students about the influence of conflictresolution strategies on relationships (Çiftci, Demir, and Bikos 2008), an interaction was shown based on the type of relationships and on a loneliness scale.

About the development of a democratic classroom atmosphere (Buluc 2006), students looking back on their high school years indicated that they understood the importance of rules for providing discipline and order, and further that the rules failed 'to teach respect for authority and the teachers are not fully able to prepare rules. In addition, it is observed that those concerned in the rule preparation process (students, parents, the school administration) do not participate in the process adequately, and regulations have not been prepared in keeping with the level students are at their education, student psychology, and their learning styles' (Buluc 2006, 49).

\section{Discussion}

Having summarised briefly these research findings on Turkish adolescents' SEL needs from 2000 to 2012, let us turn now to consider trends with direct implications on curriculum development and related policy matters, along with four research gaps.

Social-emotional components are explicitly part of national goals of Turkish education (Ministry of National Education 1973); however, this review revealed that realisation of these goals by developing appropriate curricula required careful attention. It is known that the Turkish educational system produces large variance in basic academic skills among school types that vary in selectivity (Alacaci and Erbaş 2010). We know that social and emotional competencies such as attitudes of self, responsibility and resilience are closely tied to academic performance (e.g. Arslan 2012; Yilmaz and Sipahioğlu 2012). Furthermore, more research in targeted SEL curriculum should be developed especially in less-selective schools which tend to have more harsh school climates. This in turn could help support students' mental health, positive student-teacher relationships and other social skills. Research about contextualised SEL curricula could indicate ways for cultivating valued competencies such as positive self-images (Cenkseven 2002), coping strategies (Öngen 2002), and empathy and collaboration (Dereli and Aypay 2012). This, however, requires that the contexts of these schools should be carefully studied and intervention programmes adapted from another context with sensitivity to the new context (Cubero and Perez 2013) along with necessary resources and fidelity (Bywater and Sharples 2012). Implications of this review are twofold for policy-making. First, there is a need for conducting and disseminating programmatic research on social and 
emotional learning in Turkish schools and for supporting the development of the evidence-based intervention programmes. This research should focus on improving school climate to create constructive learning communities. Particular attention should be paid to finding ways of reaching out to and meeting the needs of students from vulnerable groups such as students from poorer communities and rural areas. Second, there is also a need for increasing teacher-principal effectiveness by raising awareness about adolescents' social and emotional learning needs through professional development.

One notable research gap was the lack of studies about populations in rural areas, nearly one-quarter of the total population, with only one study about boarding schools located (Balay, Kaya, and Doğu 2012). Rural schools often serve the poorest communities in Turkey and have a special group of boarding schools known as 'YİBO' (Yatılı Illkögretim Bölge Okulu in Turkish). These schools may have their own distinct needs related to social-emotional learning. According to the Ministry of Education (2010), there were 574 YIBOs in Turkey with about 265,000 students. These schools serve students coming from disadvantaged backgrounds or students from scarcely populated regions. If research is being conducted or published about these populations, it was not found in the journals reviewed, or else it was not made explicit in how the research was reported. There is a possibility that research about SEL in urban contexts may be a matter of convenience for researchers and academicians.

A second gap is in the methodologies of qualitative research. Only 9 of the 52 studies included any qualitative or mixed method techniques, and even those often did not make direct connections with sociological, cultural theories and contextual issues within each study. For some years, educational researchers in other countries have been integrating a variety of qualitative techniques (Merriam 1998; Clandinin and Connelly 2000; Creswell 2007), which include the examination of social and emotional issues facing adolescents (e.g. Cullingford and Morrison 2006; Rodham et al. 2006). In addition, while there were few studies of this depth in Turkish SEL research literature, not one attended to time trends of adolescent needs. Experience in other cultures shows that studies reporting on changes in adolescent needs ought to be methodologically sensitive, for example, to changing social conditions and to issues of changing social acceptability of behaviours (Myers 2012). Thirdly, some research reviewed by this study had a tendency to avoid discussing the potential role of the responsibilities of a whole school or school systems in addressing the needed changes. This is a telling feature of Turkish research, in contrast to other countries where pastoral care (de Jong and Kerr-Roubicek 2007; Dagley et al. 2007), school climate (Cohen 2006) and supportive learning environments in schools (Durlak, Weissberg, and Pachan 2010; Durlak et al. 2011) are a focus for research and discourse about improving schools.

Finally, a fourth gap is a general lack of theory development. Geographically and culturally, Turkey resides at a unique crossroads of the world between the East and the West, yet the tendencies of many authors have been to use theoretical constructs developed in the West and by Western theorists with limited consideration as to how these theories are necessarily applicable and relevant to the unique tensions faced by Turkish adolescents. A more 'culturally responsive pedagogy' has been recommended for Turkey elsewhere as well (Altinyelken 2011). Indeed, Turkish adolescents may have distinct needs for certain types of SEL opportunities and challenges than adolescents in more western contexts (Bacanl1 2012). 


\section{Conclusion}

We reviewed 52 published articles to consider research trends related to Turkish adolescents, especially regarding social and emotional needs. Specifically, we examined studies on attitudes about self and other, as well as the social skills and positive social behaviours of adolescents.

We feel that this review provides a window into some of Turkey's most noteworthy research about adolescents' social and emotional needs. However, two notable limitations underlie this analysis. Firstly, we chose a broad framework of social and emotional learning that in itself has been defined outside of Turkish culture. We think that this framework has international implications due to its breadth of applicability towards the non-academic aspects of students' well-being and the research that supports it (Bywater and Sharples 2012; Berkowitz and Bustamante 2013); still, it should be noted that if Turkish theorists and educators were to examine social and emotional learning from a grounded research perspective, the definitions and framework for SEL itself could be conceptualised in different ways. The second limitation of this study was that it began with an examination of research journals published in English and in Turkey's four SSCI journals on general education. A closer examination of theses, dissertations, conference proceedings and lesser known journals would yield a more detailed view, especially in the search for replication studies.

Overall, while there are some positive SEL findings, other indicators are that Turkish adolescents' non-academic needs could and should be better addressed. There is indeed evidence elsewhere that adolescents' positive social-emotional development is supported by processes across multiple psycho-ecological systems such as peers and schools (Larson 2011). Schools are one of the places where such needs can be addressed through the design of curricula and the improvement of organisational climates (Eccles and Roeser 2011; Snyder and Flay 2012). Furthermore, we also know that supporting adolescents' positive social-emotional development contributes to their academic performance as well (Durlak et al. 2011).

As the authors of one study summarised, there is 'a need for more education programmes to be aimed at students relating to the problems that they may experience during the period of adolescence' (Unsal and Ayranci 2008, 287). Of course, prior to any large-scale movement in this direction, research is first needed that shows how the implementation of such programmes can be done successfully.

Across the 52 studies that we analysed, several trends and research gaps were especially prominent. Trends include the need for researching targeted SEL competencies within the Turkish curriculum, along with policy needs to support evidencebased interventions especially related to school climate, and policies to support the professional development of teachers and principals to improve their understanding of SEL. Gaps that future researchers of SEL-related curriculum would do well to address are as follows: (1) rural contexts, (2) qualitative and longitudinal studies, (3) school climates with SEL-supportive programmes and (4) theory development with respect to the Turkish culture.

\section{Acknowledgements}

Special thanks to Dr. Margaret Sands for her patience and valued feedback at several stages in the development of this paper. 


\section{Notes on contributors}

Robin Ann Martin is an assistant professor at the Bilkent Graduate School of Education in Ankara, Turkey. Her research interests include social and emotional learning among adolescents, along with research on positive youth development through the Creativity, Action, Service programmes within the International Baccalaureate schools of Turkey.

Cengiz Alacaci is a professor of education at Istanbul Medeniyet University in Istanbul, Turkey. He conducts research on teacher education; textbook development and analysis; teaching and learning in mathematics; and social and emotional learning in school environments.

\section{References}

Akbaş, Oktay. 2012. "Reasons for High School Students to Mistrust Most People: A Study in the Context of Values Education." Education and Science [Eğitim ve Bilim] 12 (2): 603-608.

Aksit, N. 2007. "Educational Reform in Turkey." International Journal of Educational Development 27 (2): 129-137. doi:10.1016/j.ijedudev.2006.07.011. http://linkinghub.else vier.com/retrieve/pii/S0738059306000836.

Alacaci, Cengiz, and Ayhan Kürşat Erbaş. 2010. "Unpacking the Inequality among Turkish Schools: Findings from PISA 2006." International Journal of Educational Development 30 (2): 182-192. doi:10.1016/j.ijedudev.2009.03.006. http://linkinghub.elsevier.com/ retrieve/pii/S0738059309000376.

Allen, Joseph P., and Nell Manning. 2007. "From Safety to Affect Regulation: Attachment from the Vantage Point of Adolescence." New Directions for Child and Adolescent Development 2007 (117): 23-39. doi:10.1002/cd.

Altinyelken, Hülya Kosar. 2011. "Student-centred Pedagogy in Turkey: Conceptualisations, Interpretations and Practices." Journal of Education Policy 26 (2): 137-160. doi:10.1080/02680939.2010.504886. http://www.tandfonline.com/doi/abs/10.1080/02680939. 2010.504886.

Altıparmak, Saliha, Şafak Taner, Meral Türk Soyer, and Erhan Eser. 2012. "Bornova İlköğretim İkinci Kademe Devlet Okullarında ki Ergenlerde Yaşam Kalitesi [The Quality of Life of Adolescents in Secondary Public Schools in Bornova, İzmir]." Anadolu Psikiyatri Dergisi 13: 167-173.

Aricak, Tolga, Sinem Siyahhan, Aysegul Uzunhasanoglu, Sevda Saribeyoglu, Songul Ciplak, Nesrin Yilmaz, and Cemil Memmedov. 2008. "Cyberbullying among Turkish Adolescents." Cyber Psychology and Behavior 11 (3): 253-261. doi:10.1089/cpb.2007.0016. http://www.ncbi.nlm.nih.gov/pubmed/18537493.

Arslan, Ali. 2012. "Predictive Power of the Sources of Primary School Students' Self-efficacy Beliefs on their Self-efficacy Beliefs for Learning and Performance." Educational Sciences: Theory \& Practice 12 (3): 1915-1920.

Aslan, Neşe, and Belgin Arslan Cansever. 2012. "Ergenlerin Boş Zaman Değerlendirme Algıs1 [Leisure Perceptions of Adolescents]." Hacettepe Üniversitesi Eğitim Fakültesi Dergisi 42: 23-35.

Avcı, Nabi. 2013. Millî Eğitim Bakanı Nabi Avcı'nın TBMM Genel Kurulunda 2014 Bütçe Sunuş Konuşması [Minister of National Education Nabi Avcı's Presentatipn Talk at the Grand National Assembly of Turkey for 2014 Budgetary Deliberations]. Turkey: Ankara.

Bacanlı, Hasan. 2012. Sosyal Beceri Eğitimi [Social Skills Education]. 4th ed. Ankara, Turkey: Pegem A Publications.

Bacanl1, Hasan, and Filiz Erdoğan. 2003. "Adaptation of the Matson Evaluation of Social Skills with Youngsters (MESSY) to Turkish.” Kuram ve Uygulamada Eğitim Yönetimi [Educational Sciences: Theory and Practice] 3 (2): 351-379.

Balay, Refik, Ahmet Kaya, and Zekiye Doğu. 2012. "Ortaöğretim Pansiyonlarinda Kalan Lise Ögrencilerinin Öğretmen-Öğrenci Ilişkisine Ilişkin Görüşleri [Views of Secondary School Students Staying in a Boarding House about their Relationship with Teachers]." Elektronik Sosyal Bilimler Dergisi [Electronic Journal of Social Sciences] 11 (42): 103-128.

Bayar, Yusuf, and Zehra Uçanok. 2012. "School Social Climate and Generalized Peer Perception in Traditional and Cyberbullying Status." Educational Sciences: Theory \& Practice 12 (4): 2352-2358. 
Bayramkaya, Ersin, Fevziye Toros, and Cengiz Özge. 2005. "Ergenlerde Sosyal Fobi Ile Depresyon, Öz Kavram, Sigara Alışkanlığı Arasındaki Ilişki [The Relationship between Social Phobia, Self-concept, and Smoking Behavior in Adolescents]." Klinik Psikofarmokoloji Bülteni 15: 165-173.

Berkowitz, M. W., and A. Bustamante. 2013. "Using Research to Set Priorities for Character Educatin in Schools: A Global Perspective." KEDI Journal of Educational Policy Special Is 10: 7-20.

Biçak, Bayram. 2003. "Teachers' Point of Views on Affective Domain Applications in the Secondary Elementary Schools." Abant İzzet Baysal Üniversitesi Eğitim Fakültesi Dergisi 3 (2): 39-55.

Buluc, Bekir. 2006. "An Analysis of Classroom Rules in Secondary Schools in Turkery." Educational Research Quarterly 29 (3): 30-51.

Bywater, Tracey, and Jonathan Sharples. 2012. "Effective Evidence-based Interventions for Emotional Well-being: Lessons for Policy and Practice." Research Papers in Education 27 (4): 389-408. doi:10.1080/02671522.2012.690242. http://www.tandfonline.com/doi/ abs/10.1080/02671522.2012.690242.

Camadan, Fatih, and Galip Yüksel. 2012. "Türk Ortaöğretim Öğrencilerinde Mükemmeliyetçilik [Perfectionism among Turkish Secondary Students]." Gaziantep Üniversitesi Sosyal Dergisi 11 (3): 701-714.

Cenkseven, Fulya. 2002. "Effects of Gender and Gender Roles on Adolescents' Self Images." Eğitim ve Bilim 27 (125): 28-35.

Cenkseven-Önder, Fulya. 2012. "The Influence of Decision-making Styles on Early Adolescents' Life Satisfaction." Social Behavior and Personality 40 (9): 1523-1536.

Çetin, Füsun Çuhadaroğlu, Zeynep Tüzün, Berna Pehlivantürk, Fatih Ünal, and Bahar Gökler. 2010. "Attachment Styles and Self-image in Turkish Adolescents." Journal of Research on Adolescence 20 (4): 840-848. doi:10.1111/j.1532-7795.2010.00674.x. http:// doi.wiley.com/10.1111/j.1532-7795.2010.00674.x.

Çiftci, Ayşe, Ayhan Demir, and Lynette Heim Bikos. 2008. "Turkish Adolescents' Conflict Resolution Strategies toward Peers and Parents as a Function of Loneliness." Adolescence 43 (172): 911-926.

Çivitci, Asım. 2009. "Life Satisfaction in Primary School Students: The Role of Some Personal and Familial Factors." Uludağ Üniversitesi Eğitim Fakültesi Dergisi XXII 1: 29-52.

Clandinin, D. Jean, and F. Michael Connelly. 2000. Narrative Inquiry: Experience and Story in Qualitative Research. San Francisco, CA: Jossey-Bass.

Cohen, Jonathan. 2006. "Social, Emotional, Ethical, and Academic Education: Creating a Climate for Learning, Participation in Democracy, and Well-being." Harvard Educational Review 76 (2): 201-237.

Craig, Wendy, Yossi Harel-Fisch, Haya Fogel-Grinvald, Suzanne Dostaler, Jorn Hetland, Bruce Simons-Morton, Michal Molcho, et al. 2009. "A Cross-national Profile of Bullying and Victimization among Adolescents in 40 Countries." International Journal of Public Health 54 (Suppl. 2): S216-S224. doi:10.1007/s00038-009-5413-9. http://www.pubmed central.nih.gov/articlerender.fcgi?artid=2747624\&tool=pmcentrez\&rendertype=abstract.

Creswell, John W. 2007. Qualitative Inquiry \& Research Disign: Choosing among Five Approaches. Thousand Oaks, CA: Sage.

Cubero, Luis Nunez, and Clara Romero Perez. 2013. "Promoting Emotional, Social and Civic Competencies: Educational Policies in Spain." KEDI Journal of Educational Policy Special Is 10: 65-80.

Cullingford, Cedric, and Jenny Morrison. 2006. "Peer Group Pressure within and Outside School." British Educational Research Journal 23 (1): 61-80.

Dagley, Valerie, Amanda Howe, Charlotte SALTER, Primary Care, Marian Brandon, Catherine Warren, and Social Work. 2007. "Implications of the New Common Assessment Framework and Lead Professional Working for Pastoral Care Staff in Schools." Pastoral Care 25: 4-10.

Dereli, Esra, and Ay Aypay. 2012. "The Prediction of Empathetic Tendency and Characteristic Trait of Collaboration on Humane Values in Secondary Education Students and the Examining of Those Characteristics." Educational Sciences: Theory \& Practice 12 (2): 1262-1270. 
Doğan, Türkan, Neslihan G. Karaman, Aysel E. Çoban, and Figen Çok. 2012. "Ergenlerde Arkadaşlık Ilişkilerinin Yordayıcısı Olarak Cinsiyet ve Aileye Ilişkin Değişkenler [Predictors of Adolescents' Friendship Qualities: Gender and Family Related Variables]." Elementary Education Online / Illkögretim Online 11 (4): 1010-1020.

Doğanay, Ahmet. 2010. "What does Democracy Mean to 14-year-old Turkish Children? A Comparison with Results of the 1999 IEA Civic Education Study." Research Papers in Education 25 (1): 51-71. doi:10.1080/02671520802315060. http://www.tandfonline.com/ doi/abs/10.1080/02671520802315060.

Durlak, Joseph A., Roger P. Weissberg, Allison B. Dymnicki, Rebecca D. Taylor, and Kriston Schellinger. 2011. "The Impact of Enhancing Students' Social and Emotional Learning: A Meta-analysis of School-based Universal Interventions." Child Development 82 (1): 405-432. doi:10.1111/j.1467-8624.2010.01564.x. http://www.ncbi.nlm.nih.gov/pubmed/ 21291449.

Durlak, Joseph A., Roger P. Weissberg, and Molly Pachan. 2010. “A Meta-analysis of After-school Programs that Seek to Promote Personal and Social Skills in Children and Adolescents." American Journal of Community Psychology 45: 294-309. doi:10.1007/ s10464-010-9300-6. http://www.ncbi.nlm.nih.gov/pubmed/20300825.

Eccles, Jacquelynne S., and Robert W. Roeser. 2011. "Schools as Developmental Contexts During Adolescence." Journal of Research on Adolescence 21 (1): 225-241. doi:10.1111/ j.1532-7795.2010.00725.x. http://doi.wiley.com/10.1111/j.1532-7795.2010.00725.x.

Ecclestone, Kathryn. 2012a. "Emotional Well-being in Education Policy and Practice: The Need for Interdisciplinary Perspectives and a Sociological Imagination." Research Papers in Education 27 (4): 383-387. doi:10.1080/02671522.2012.690245. http://www.tandfon line.com/doi/abs/10.1080/02671522.2012.690245.

Ecclestone, Kathryn. 2012b. "From Emotional and Psychological Well-being to Character Education: Challenging Policy Discourses of Behavioural Science and 'Vulnerability'." Research Papers in Education 27 (4): 463-480. doi:10.1080/02671522.2012.690241. http://www.tandfonline.com/doi/abs/10.1080/02671522.2012.690241.

Elias, M. J. 2013. "Educational Policy and the Responsibility of the School for Promoting Students Social-emotional, Character, and Moral Development and Preventing Bullying: Introduction to Special Issue." KEDI Journal of Educational Policy 10: 3-5.

Eryilmaz, Ali. 2011. "Satisfaction of Needs and Determining of Life Goals: A Model of Subjective Well-being for Adolescents in High School." Educational Sciences: Theory \& Practice 11 (4): 1757-1764.

Geçk1l, Emine, and Özlem Dündar. 2011. "Turkish Adolescent Health Risk Behaviors and Self-Esteem." Social Behavior and Personality 39 (2): 219-227. doi:10.2224/sbp.2011. 39.2.219. http://openurl.ingenta.com/content/xref?genre $=$ article \&issn $=0301-2212 \&$ volume $=$ 39 \&issue $=2$ \&spage $=219$.

Gizir, Cem Ali, and Gul Aydin. 2009. "Protective Factors Contributing to the Academic Resilience of Students Living in Poverty in Turkey." Professional School Counseling 13 (1): $38-49$.

Gümüş, Sedat, and Erkan Hasan Atalmis. 2012. "Achievement Gaps between Different School Types and Regions in turkey: Have they Changed over Time?" Mevlana International Journal of Education 2 (2): 50-66.

Güven, Mehmet, and Sevda Aslan. 2010. "The Separation-Individuation and Perceived Parenting Styles in Adolescence.” Eurasian Journal of Educational Research 117-132.

Harel-Fisch, Yossi, Sophie D. Walsh, Haya Fogel-Grinvald, Gabriel Amitai, William Pickett, Michal Molcho, Pernille Due, Margarida Gaspar de Matos, and Wendy Craig. 2011. "Negative School Perceptions and Involvement in School Bullying: A Universal Relationship across 40 Countries." Journal of Adolescence 34 (4): 639-652. doi:10.1016/ j.adolescence.2010.09.008. http://www.ncbi.nlm.nih.gov/pubmed/21168202.

Hofstede, G. 1993. "Cultures and Organizations: Software of the Mind." Administrative Science Quarterly 38 (1): 132-134.

de Jong, Terry, and Helen Kerr-Roubicek. 2007. "Towards a Whole School Approach to Pastoral Care: A Proposed Framework of Principles and Practices." Australian Journal of Guidance and Counselling 17 (1): 1-12. doi:10.1375/ajgc.17.1.1. http://journals.cam bridge.org/abstract_S1037291100000467. 
Kabakçı, Ömer Faruk, and Fidan Korkut. 2008. "The Study of Students' Social-Emotional Learning Skills in Terms of Some Variables at 6-8 Grade Level." Eğitim ve Bilim [Education and Science] 33 (148): 77-86.

Kapikiran, Şahin. 2012. "Achievement Goal Orientations and Self Handicapping as Mediator and Moderator of the Relationship between Intrinsic Achievement Motivation and Negative Automatic Thoughts in Adolescent Students." Educational Sciences: Theory \& Practice 12 (2): 705-711.

Kapikiran, Şahin, and Ufuk Yağcı. 2012. "Ergenlerin Yalnızlık ve Yaşam Doyumu: Çalgı Çalma ve Müzik Topluluğuna Katılmanın Aracı ve Farklılaştırıcı Rolü [Loneliness and Life Satisfaction of Adolescents: The Mediator and Moderator Role of Playing Musical Instruments and Joining a Band].” Elementary Education Online 11 (3): 738-747.

Kesici, Şahin. 2007a. "Middle School Students' Guidance and Counseling Needs." Educational Sciences: Theory \& Practice 7 (3): 1325-1350.

Kesici, Şahin. 2007b. "6th, 7th, and 8th Grade Students' Guidance and Counseling Needs According to the Views of the Classroom Teachers." Selçuk Universitesi Sosyal Bilimler Enstitusu Dergisi 17:365-383.

Kiliç, Serpil, Erhan Çene, and İbrahim Demir. 2012. "Comparison of Learning Strategies for Mathematics Achievement in Turkey with Eight Countries." Educational Sciences: Theory \& Practice 12 (4): 2594-2599.

Kumru, Asiye, Gustavo Carlo, and V. Mestre MariaPaula Samper. 2012. "Prosocial Moral Reasoning and Prosocial Behavior among Turkish and Spanish Adolescents." Social Behavior and Personality 40 (2): 205-214.

Lambert, Paul, Jonathan Scourfield, Nina Smalley, and Raya Jones. 2008. "The Social Context of School Bullying: Evidence from a Survey of Children in South Wales." Research Papers in Education 23 (3): 269-291. doi:10.1080/02671520701809866. http:// www.tandfonline.com/doi/abs/10.1080/02671520701809866.

Larson, Reed W. 2011. "Positive Development in a Disorderly World." Journal of Research on Adolescence 21 (2): 317-334. doi:10.1111/j.1532-7795.2010.00707.x. http://doi.wiley. $\mathrm{com} / 10.1111 / \mathrm{j} .1532-7795.2010 .00707 . \mathrm{x}$.

Martin, Robin. 2012. "Social and Emotional Learning Research: Intervention Studies for Supporting Adolescents in Turkey." Istanbul: International Conference on Education and Educational Psychology.

Merriam, Sharan B. 1998. Qualitative Research and Case Study Applications in Education. San Francisco, CA: Jossey-Bass.

Ministry of National Education. 1973. "Milli Eğitim Temel Kanunu [Basic Law of National Education]." http://mevzuat.meb.gov.tr/html/88.html.

Ministry of National Education. 2005. "Yeni İlköğretim Programları ve Yeni Yaklaşımlar [New Primary Education Curricula and New Approaches].” http://iogm.meb.gov.tr/pages. php?page= program.

Ministry of National Education. 2010. Cumhuriyet Döneminde Türk Millî Eğitimindeki Gelişmeler [Developments in Turkish National Educational System during Republican Era]. Turkey: Ankara.

Ministry of National Education. 2013. Monitoring and Evaluation Report for Secondary Education 2013 [Ortaöğretim İzleme ve Değerlendirme Raporu: 2013]. Turkey: Ankara.

Myers, Kevin. 2012. "Marking Time: Some Methodological and Historical Perspectives on the 'crisis of childhood'." Research Papers in Education 27 (4): 409-422. doi:10.1080/02671522.2012.690237. http://www.tandfonline.com/doi/abs/10.1080/02671522. 2012.690237.

OECD. 2013. Education Policy Outlook: Turkey. Paris: OECD. http://www.oecd.org/edu/ED UCATIONPOLICYOUTLOOKTURKEY EN.pdf.

Öngen, Demet. 2002. "Coping Behaviors of Ādolescents.” Ĕgitim ve Bilim 27 (125): 54-61.

Öngen, Demet. 2004. "The Differences between Adolescent-Mother and Adolescent-Father Relationships during the Process of Achieving Autonomy." Education and Science 29 (131): 3-13.

Özabac1, Nilüfer. 2011. "An Investigation of Concepts and Words Used by Turkish Children and Teenagers to Define their Perceptions Regarding Events Involving Emotional Situations." Collegium Antropologium 2 (35): 289-298. 
Özdemir, Murat. 2012. "Lise Öğrencilerinin Metaforik Okul Algılarının Çeşitli Değişkenler Açısından İncelenmesi [Examination of High School Students ' Metaphorical School Perceptions in Terms of Various Variables]." Education and Science [Eğitim ve Bilim] 37 (163): 96-109.

Özdemir, Yalçın. 2012. "Ergenlerin Öznel İyi Oluşunun Demografik Değişkenler, Ana-Baba Kontrolü ve Ana-Baba Kabul/ilgisi Açısından İncelenmesi [Examining the Subjective Well-being of Adolescents in Terms of Demographic Variables, Parental Control, and Parental Warmth]." Education and Science [Eğitim ve Bilim] 37 (165): 20-32.

Öztürk, İbrahim Hakk1. 2011. "Curriculum Reform and Teacher Autonomy in Turkey: The Case of the History Teaching." International Journal of Instruction 4 (2): 113-128.

Rodham, Karen, Helen Brewer, Willm Mistral, and Paul Stallard. 2006. "Adolescents' Perception of Risk and Challenge: A Qualitative Study." Journal of Adolescence 29 (2): 261-272. doi:10.1016/j.adolescence.2005.05.012. http://www.ncbi.nlm.nih.gov/pubmed/ 16214211.

Santrock, John W. 2001. Educational Psychology. International ed. New York: McGraw-Hill.

Sarı, Mediha. 2012. "Sense of School Belonging among Elementary School Students." Çukurova University Faculty of Education Journal 41 (1): 1-11.

Sarı, Mediha, Sezen Sarı, and Mine Suat Ötünç. 2008. "An Investigation of Devotion to Democratic Values and Conflict Resolution Abilities : A Case of Elementary School Students." Educational Sciences: Theory \& Practice 8 (1): 183-192.

Sklad, Marcin, Rene Diekstra, Monique De Ritter, Jehonathan Ben, and Carolien Gravesteijn. 2012. "Effectiveness of School-based Universal Social, Emotional, and Behavioral Programs: Do they Enhance Students' Development in the Area of Skill, Behavior, and Adjustment?" Psychology in the Schools 49 (9): 892-909. doi:10.1002/pits.

Snyder, F. J., and B. R. Flay. 2012. "Positive Youth Development." In Handbook on Prosocial Education. Vol. 2, edited by P. M. Brown, M. Corrigan, and A. Higgins-D’Allesandro, 415-443. New York: Rowman and Littlefield.

Taşdemir, Adern. 2012. "Değerlere Ilişkin Türkiye, Irak, Suudi Örneklemindeki Türk Öğrencilerin Görüşleri [Turkish Students' Views about Values from Samples in Turkey, Iraq, Saudi Arabia]." Educational Sciences: Theory \& Practice 12 (3): 1707-1736.

Telli, Sibel, Perry Den Brok, and Jale Çakıroğlu. 2008. "Öğretmen ve Öğrencilerin İdeal Öğretmen Hakkındaki Görüşleri [Teachers' and Students' Perceptions of the Ideal Teacher]." Eğitim ve Bilim 33 (149): 118-129.

İpek, Cemalettin, and Ali Rıza Terzi. 2010. "İlk ve Ortaöğretim Kurumlarında Öğrenci Ilişkilerinin Öğretmen Görüşlerine Göre Belirlenmesi: Van İli Örneği.” [Investigating Teacher-student Relationships in the Primary and Secondary Schools Based on Teachers' Views: The Case of Van City] Kuram ve Uygulamada Eğitim Yönetimi [Educational Administration: Theory and Practice] 16 (3): 433-456.

Titrek, Osman. 2009. “Ögretmen Görüşlerine Göre Türkiye'de Ortaögretim Sistemindeki Son Sinıf Ögrencilerinin Duygusal Zekâ (EQ) Düzeyleri [Emotional Intelligence (EQ) Levels of the Senior Students in Secondary Education System in Turkey Based on Teacher's Perceptions].” International Journal of Human Sciences 6 (1): 712-730.

Türnüklü, Abbas, and İdris Şahin. 2004. "13-14 Yaş Grubu Öğrencilerin Çatışma Çözme Stratejilerinin Incelenmesi [An Investigation of Conflict Resolution Strategies of 13-14 Years Old Students]." Türk Psikoloji Yazılart 7 (13): 45-61.

Türnüklü, Abbas, İdris Şahin, and Namık Öztürk. 2002. "Conflict Resolution Strategies of Students, Teachers, Principals, and Parents in Primary School." Kuram ve Uygulamada Eğitim Yönetimi [Educational Sciences: Theory and Practice] 32: 574-597.

Unsal, Alaaddin, and Unal Ayranci. 2008. "Prevalence of Students with Symptoms of Depression among High School Students in a District of Western Turkey: An Epidemiological Study." The Journal of School Health 78 (5): 287-293. doi:10.1111/j.17461561.2008.00302.x. http://www.ncbi.nlm.nih.gov/pubmed/18387029.

Weare, Katherine, and Melanie Nind. 2011. "Promoting Mental Health of Children and Adolescents through Schools and School Based Interventions: Evidence Outcomes." School Based Interventions Report of Workpackage Three of the DATAPREV Project, School of Education, University of Southhampton. 
Yildirim, İbrahim. 2000. “Akademik Başarinin Yordayicisi Olarak Yalnızlık, Sinav Kaygısı ve Sosyal Destek [Loneliness, Test Anxiety and Social Support as Predictors of Academic Achievement]." Hacettepe Üniversitesi Eğitim Fakültesi Dergisi 18: 167-176.

Yildirim, İbrahim. 2006. "Akademik Başarının Yordayıcısı Olarak Gündelik Sıkıntılar ve Sosyal Destek." [Daily Hassles and Social Support as Predictors of Academic Achievement] Hacettepe Üniversitesi Eğitim Fakültesi Dergisi 30: 258-267.

Yilmaz, Hasan, and Önder Sipahioğlu. 2012. "Farklı Risk Gruplarındaki Ergenlerin Psikolojik Sağlamlıklarının Incelenmesi [Investigating Resilience of Adolescents in Different Risk Groups]." Elementary Education Online 11 (4): 927-944. 